\title{
НОВІ КОНСТРУКТИВНІ РІШЕННЯ ПРИ ВИМІРЮВАННІ ЕНЕРГЕТИЧНИХ ПАРАМЕТРІВ ЛАЗЕРНОГО ВИПРОМІНЮВАННЯ ДЛЯ ПОТРЕБ ПОЛІГРАФІЧНИХ ВИРОБНИЦТВ
}

\author{
( В. В. Романенко, к.т.н., доцент, НТУУ «КПІ», Київ, Україна
}

В данной работе на основе анализа существующих приборов для измерения энергии и мощности излучения лазерного оборудования предложены оригинальные устройства для таких измерений для нужд полиграфической промышленности, которые отличаются простотой и надежностью и существенно расширяют возможности своего применения.

In this work on the basis of analysis of existent devices for measuring of energy and power of radiation of laser equipment original devices offer for such measuring for the needs of polygraphy industry, that differ in simplicity and reliability and substantially extend possibilities of the application.

\section{Постановка проблеми}

Нині спостерігається стійка тенденція по все більшому впровадженню лазерних установок практично в усі області сучасного виробництва, у тому числі і в сферу технологічних процесів в поліграфічній промисловості. При цьому, природно, бажаний, a іноді і потрібний постійний оперативний контроль за параметрами застосовуємого лазерного випромінювання. Проте складність, висока вартість, громіздкість і необхідність висококваліфікованого обслуговування утрудняє у багатьох випадках практичне використання таких пристроїв. На ціноутворення робить вплив і той чинник, що в Україні такі вимірювачі не випускаються. Тим актуальніше завдання створення в Україні оперативного вимірювача таких параметрів лазерного випромінювання, як енергія і потужність.
Найбільш широке поширення для виміру таких усереднюваних в часі енергетичних параметрів лазерного випромінювання, як енергія і середня потужність, отримали калориметри, а точніше калориметри змінної температури. Будь-яка калориметрична система містить власне калориметр або внутрішнє калориметричне тіло, в якому протікає процес виділення (чи поглинання) тепла, і зовнішню оболонку, 3 якою відбувається теплообмін калориметричного тіла шляхом теплопровідності, конвекції і випромінювання. Теплообмін між калометричним тілом і оболонкою визначається в першу чергу різницею температур їх поверхонь. Проте такі приймачі $\epsilon$ непрохідними, що складає їх основний недолік [1].

Основою фотоелектричного принципу вимірювального перетворення енергетичних параметрів оптичного випроміню- 
вання $є$ поглинання фотона, що супроводжується електрично реєстрованим переходом носіїв заряду на більш високі енергетичні рівні. Вихідний електричний сигнал таких приймачів залежить не від потужності випромінювання, що падає, а від кількості квантів випромінювання і енергії кожного кванта.

У зв'язку з розвитком потужних технологічних лазерів, працюючих у безперервному режимі виникла необхідність в широкоапертурних вимірниках потужності, працюючих в прохідному режимі. Нині потужність технологічних лазерів досягла 20 кВт і має тенденцію до подальшого зростання. Традиційно такі завдання вирішувалися за допомогою відгалужувача невеликої частини (0,1-1,0 \%) вимірюваного потужного випромінювання. Так, наприклад, відомі способи виміру прохідної потужності безперервного лазерного випромінювання в прохідному режимі, що полягає або в просторово-часовому відгалуженні не більше 1 \% вимірюваної потужності дзеркалами (дзеркальними спицями), що обертаються упоперек випромінювання, клинами, діафрагмами та ін., або у використанні болометра (дротяного приймача, що з певним кроком перетинає лазерний промінь). Прийом лазерного випромінювання, в першому випадку, здійснюється калориметричним вимірником середньої потужності, а в другому широкоапертурним приймачем, що формує імпульсні сигнали, амплітудне значення яких є мірою миттєвої потужності.

Недоліками таких вимірювачів є складність технічної реалізації, невисока надійність пристроїв, оскільки відгалужуючі дзеркала обертаються з великою швидкістю, а болометричні приймачі легко руйнуються, а також необхідність в підготовчих налаштувальних і юстирувальних операціях, що збільшує реальний час виміру [1].

\section{Мета роботи}

Завданням представленої роботи $є$ розробка простих і надійних методів і засобів виміру параметрів лазерного випромінювання, а також створення на їх базі вимірювачів таких параметрів лазерного випромінювання, як енергія і потужність для потреб поліграфічних виробництв.

\section{Результати проведених досліджень}

Одним з відомих вимірювачів потужності лазерного випромінювання $є$ вимірювач прохідного типу, в якому в якості приймача випромінювання застосовується плівковий анізотропний термоперетворювач, що одноразово переміщається упоперек лазерного пучка з такою швидкістю, при якій час проектування лазерного пучка на апертурі приймача випромінювання не перевищує 0,1 с [2]. Цей вимірювач, на відміну від класичних вимірювачів потужності прохідного типу, значно зменшує теплове навантаження на приймач лазерного випромінювання, 
проте він досить складний, має малу надійність та високу вартість.

Відомим технічним рішенням для вирішення поставленої проблеми є вимірювач потужності лазерного випромінювання, що містить перетворювач потужності лазерного випромінювання в еквівалентний за величиною електричний сигнал, який генерується термобатареєю за наявності градієнта температур між ї̈ «гарячими» i «холодними» спаями. Чутливим елементом цього приймача $\epsilon$ алюмінієвий диск 3 оксидованим покриттям, який суцільно перекриває та поглинає лазерний пучок [3]. Завдяки виконанню чутливого елементу вимірювача суцільним приймачем, значно спрощується його конструкція та підвищується точність вимірювання. Проте цей вимірювач має той недолік, що він повністю перекриває лазерний пучок при вимірюванні і не може бути використаний під час експлуатації лазерного обладнання.

В основу вдосконалення приймача вимірювача енергії та потужності лазерного випромінювання покладено задачу забезпечення можливості використання вимірювача під час експлуатації лазерного обладнання, отже і більш широкі можливості його використання. Поставлена задача вирішується тим, що в вимірювачі потужності лазерного випромінювання, що містить приймач (наприклад, в вигляді алюмінієвого диска), який суцільно перекриває лазерний пучок, з абсорбційним покриттям, що поглинає лазер- не випромінювання (наприклад, керамічне напилене покриття, або оксидоване покриття), цей приймач за допомогою термобатареї перетворює потужність лазерного випромінювання в еквівалентний за величиною електричний сигнал, який генерується цією термобатареєю за наявності градієнта температур між її «гарячими» і «холодними» спаями. Різниця температур між цими спаями термобатареї може складати до $70{ }^{\circ} \mathrm{C}$, а товщина приймача (близько 1 мм) вибрана таким чином, щоб забезпечити лінійну залежність температури при різних потужностях. Адаптуючи товщину приймача, з одного боку, можливо підібрати достатню його чутливість, що дозволяє отримати постійну часу приймача в межах 2 с, а $з$ іншої - охопити діапазон, принаймні, до трьох порядків величин вимірюваних потужностей. Застосування ж абсорбуючого поглинального покриття дозволяє значно підвищити чутливість приймача.

Використання напівпровідникових термоелектричних матеріалів з оптимізованими параметрами на основі потрійних 3'єднань телуриду вісмуту дозволяє підвищити коефіцієнт перетворення і розширити діапазон вимірів ще на 1-2 порядки. При цьому термобатарея складається 3 щільно упакованих гілок n- i p-типу малого поперечного перерізу 3 ізолюючим прошарком на основі епоксидних компаундів між ними.

Згідно 3 пропонованими автором технічними рішеннями, приймач лазерного випроміню-
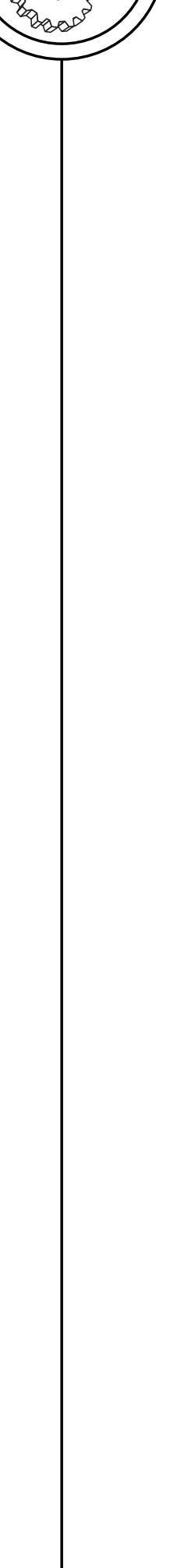
вання може бути виконаний в наступних варіантах. По-перше, в наборі як мінімум з двох приймачів: суцільного та у вигляді змінної діафрагми з центральним отвором, діаметр якого дещо менший діаметра апертури вимірюваного лазерного пучка. у найприйнятнішому прикладі змінна діафрагма може мати діаметр отвору на 10 \% менший діаметра апертури пучка. За необхідності формування лазерних пучків заданих діаметрів може застосовуватись набір змінних діафрагм потрібних діаметрів (рис. 1). По-друге, приймач лазерного випромінювання може бути виконаний двомісним та, окрім частини 3 суцільним диском, містити додаткову частину у вигляді діафрагми з центральним отвором, діаметр якого дещо менший діаметра апертури вимірюваного лазерного пучка. Аналогічно приведеній вище конструкції змінна діафрагма може мати діаметр отвору на $10 \%$ менший діаметра апертури пучка та при необхідності формування лазерних пучків потрібних заданих діаметрів може застосовуватись набір змінних діафрагм (рис. 2). По-третє, приймач може бути збірним, що складається (як мінімум) з трьох частин, які можуть знаходитися в зведеному і розведеному положенні. При цьому в зведеному положенні приймач суцільно перекриває лазерний пучок i повністю використовує його для виміру потужності, а в розведеному положенні - практично повністю пропускає лазерне випромінювання, вирізуючи для виміру його потужності по краях лазерного пучка тільки певну його частину (рис. 3).

В першому прикладі, вимірювач потужності лазерного випромінювання містить корпус 1, який має виступ 2 для розміщення приймача, в вигляді диска 3, що суцільно перекриває лазерний пучок 4 (під час налаштування) (рис. 1, а), або в вигляді діафрагми 5 з центральним отвором (під час експлуатації) (рис. 1, б) з абсорбційним покриттям 6, що поглинає лазерне випромінювання (в обох випадках - для підвищення поглинальної здатності приймача). Як суцільний 3, так і діафрагмований 5 приймач кріпиться в корпусі 1 за допомогою притискача 7, який може, наприклад, укручуватися в корпус 1 завдяки різьбовому з'єднанню. Внутрішній край виступу 2 корпусу 1 знаходиться в тепловому контакті з термостатом 8, що може мати, наприклад, водяне чи повітряне охолодження 9. Це забезпечує градієнт температури між внутрішнім (який безпосередньо контактує з приймачем лазерного випромінювання) та зовнішнім (постійно охолоджуваним) краєм виступу 2. На тильній (по відношенню до лазерного випромінювання) стороні виступу 2 корпусу 1 знаходяться термоелектричні батареї 10 (рис. 1, в), що утворюють кільце, внутрішній діаметр якого відповідає апертурі вимірювального лазерного пучка 4 («гаряча сторона»), а зовнішній - внутрішньому діаметру термостата 8 («холодна сторона»). Виходи термобатареї 10 сполучені 3 вимірювальним приладом 11, який фіксує елек- 


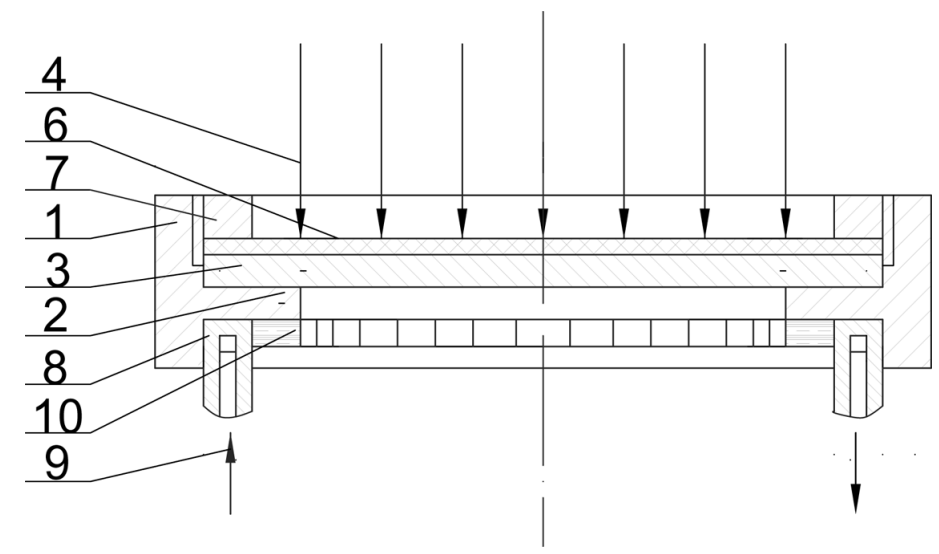

a


Рис. 1. Пристрій вимірювача енергії та потужності лазерного випромінювання з приймачем у вигляді суцільного диска (а) та у вигляді змінної діафрагми з центральним отвором (б), а також вид на термобатарею в режимі налаштування та під час експлуатації (пунктир) 


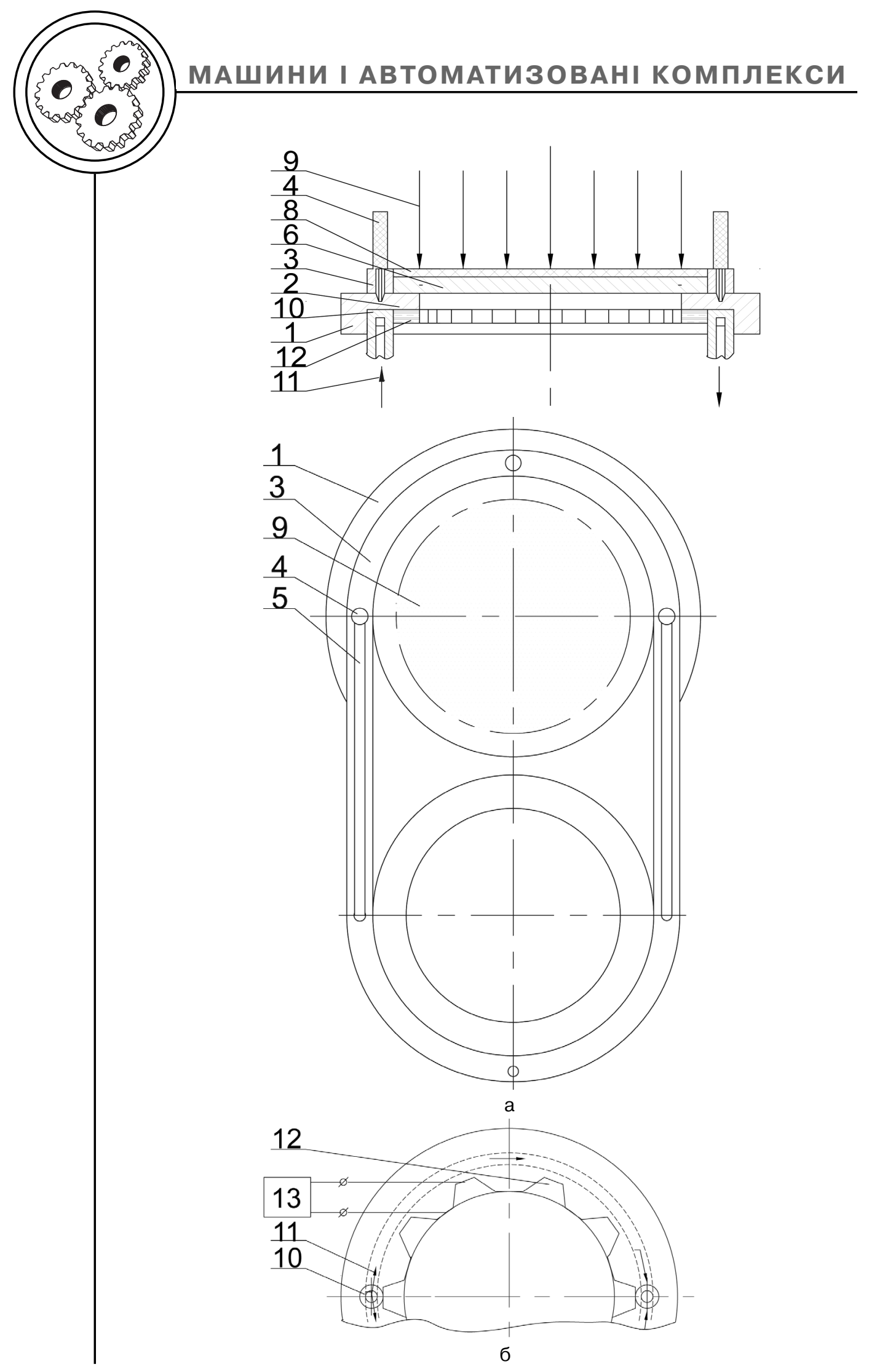

94 

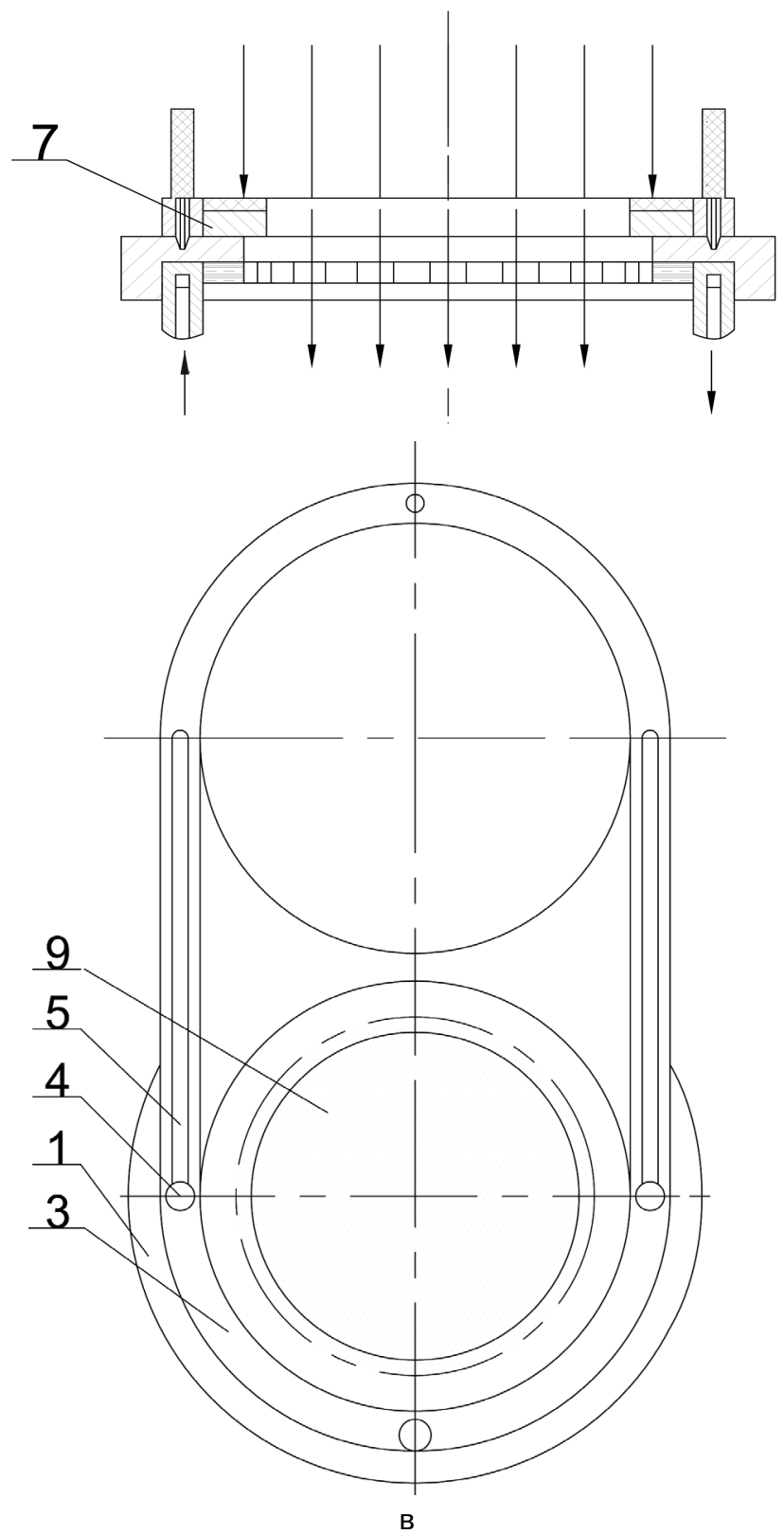

Рис. 2. Пристрій для вимірювання потужності лазерного випромінювання з двомісним приймачем: одна частина з суцільним диском (а) з видом на термобатарею в режимі налаштування (б) та інша частина у вигляді діафрагми з центральним отвором (в)

тричний сигнал, пропорційний потужності вимірюваного лазерного випромінювання.

Вимірювач потужності лазерного випромінювання описува- ної конструкції працює в такий спосіб. В режимі налаштування на виступі 2 корпусу 1 встановлюється приймач, в вигляді суцільного диска 3, що повністю 


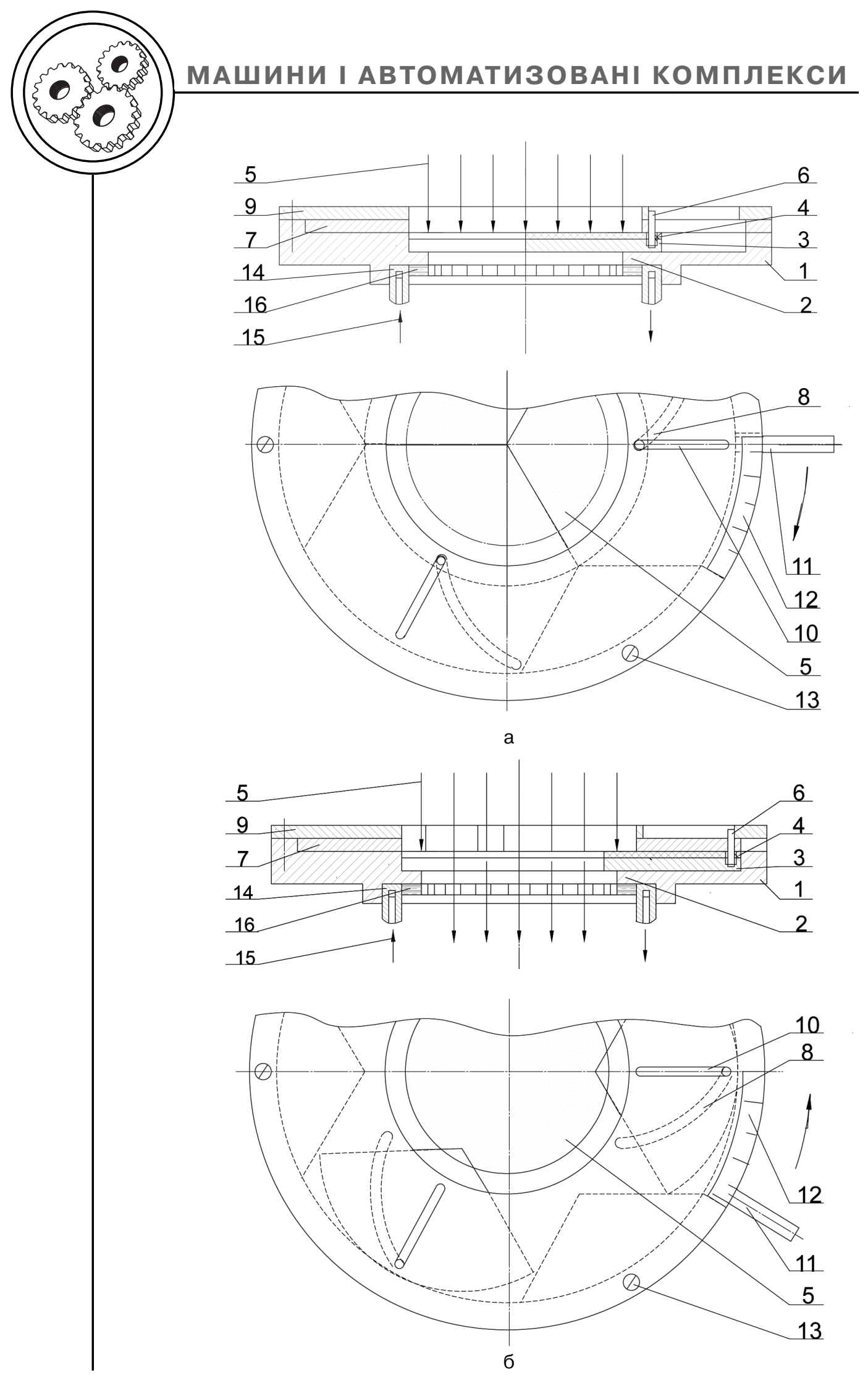

96 

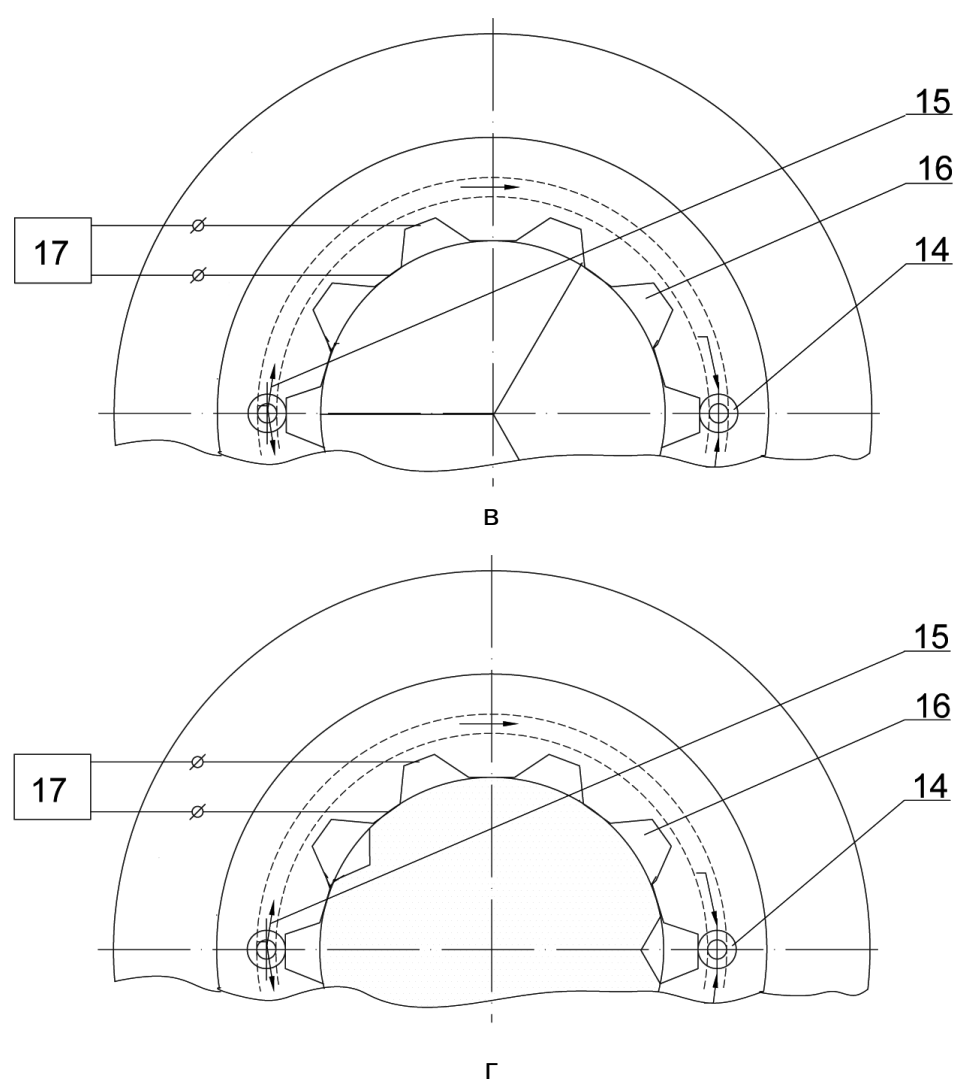

Рис. 3. Пристрій вимірювача потужності лазерного випромінювання зі збірним приймачем в зведеному (а) та розведеному (б) положенні, а також вид на термобатарею в режимі налаштування (в) та під час експлуатації (г)

перекриває лазерний пучок 4. В даному режимі приймач поглинає весь лазерний потік, вимірювач показує абсолютне значення потужності лазерного вимірювання, і вимірювальний прилад 11 відтарований належним чином. Проте при цьому вимірювач не може працювати в режимі експлуатації, оскільки не пропускає лазерне випромінювання для подальшого використання. Для переведення вимірювача в режим експлуатації приймач замінюється на приймач у вигляді змінної діафраг- ми 5 з центральним отвором, діаметр якого дещо менший діаметра апертури вимірювального лазерного пучка. Це забезпечує, з однієї сторони, проходження основної частини лазерного випромінювання для подальшого використання, a, 3 другої сторони, незначна частина (у найприйнятнішому прикладі - до 10 \%) використовується для поточного та постійного вимірювання під час експлуатації. Звичайно, при заміні суцільного 3 приймача лазерного випромінювання на 
діафрагмований 5 вимірювальний прилад 11 буде показувати інше (значно менше) значення вимірюваної потужності. Але за рахунок зміни чутливості електричної частини вимірювального приладу 11 на його шкалі встановлюється те ж значення потужності, що і при вимірі абсолютного їі значення (при використанні суцільного приймача). Аналогічно можна використати діафрагму іншого необхідного діаметру з виведенням чутливості електричної частини вимірювального приладу 11 теж на показання абсолютного значення.

Якщо в процесі експлуатації показання вимірювального приладу 11 не змінюється, то це свідчить, що потужність лазерного випромінювання теж не змінюється, і лазерне обладнання не потребує переналадки. Зміна ж відносного показання потужності випромінювання (наприклад, зменшення в результаті роз'юстування) буде сигналізувати про зміну абсолютного значення потужності, що і покаже потребу в профілактиці лазерного обладнання. Після профілактики обладнання знову потрібно вимірювач потужності спочатку встановити в режим налаштування, виміряти (використовуючи суцільний 3 приймач) абсолютне значення потужності лазерного вимірювання, а потім перевести в режим експлуатації, застосовуючи необхідний діафрагмований 5 приймач та зробивши переналаштування вимірювального приладу 11.

В другому прикладі конструкція вимірювача дуже подібна до наведеної вище. Так, вимірювач потужності випромінювання лазера містить корпус 1, який має виступ 2 для розміщення приймача в вигляді плоского фланця 3, який кріпиться на корпусі 1 за допомогою, наприклад, трьох спеціальних гвинтів 4. Для переміщення плоского фланця 3 із одного крайнього положення (режим налаштування) в інше (режим експлуатації) служать направляючі пази 5. Фланець 3 має два посадочних місця. Перше - для установки диска 6, друге - для установки діафрагми 7 з центральним отвором. Як диск, так і діафрагма мають абсорбційне покриття 8 для підвищення поглинальної здатності приймача. Диск 6 суцільно перекриває лазерний пучок 9 і використовується в режимі налаштування (рис. 2, а), тоді як діафрагма 7 з центральним отвором - під час експлуатації (рис. 2, в). Зовнішній край виступу 2 корпусу 1 знаходиться в тепловому контакті з термостатом 10 з водяним чи повітряним охолодженням 11 , а виходи термобатареї 12 сполучені 3 вимірювальним приладом 13 (рис. 2, б). В режимі налаштування на корпусі 1 за допомогою спеціальних гвинтів 4 (наприклад, $з$ головками для ручного загвинчування) закріпляється та частина плоского фланця 3, де встановлений суцільний диск 6 , що повністю перекриває лазерний пучок 9 . Для переведення вимірювача в режим експлуатації гвинти 4, що знаходяться в пазах, послабляються, а центральний (на рис. 1, а - верхній) - повністю відкру- 
чується. Плоский фланець 3 переміщується по пазах 5 в інше крайнє положення, так що місце суцільного диску 6 займає діафрагма 7. Гвинти 4, що в пазах, затискуються, а центральний - вкручується та затискується внизу (див. рис. 2, в). Крім того, в посадочне місце фланця 3 (для діафрагм) можна встановлювати діафрагму іншого необхідного діаметру.

I, нарешті, в третьому прикладі, вимірювач потужності лазерного випромінювання містить корпус 1, що має виступ 2 для розміщення приймача в вигляді збірного диска 3 з абсорбційним покриттям 4. Збірний диск 3 може бути повністю зведений, і в даному положенні (режим налаштування) суцільно перекриває лазерний пучок 5 (рис. 3, а), або в розведеному стані (режим експлуатації) (рис. 3, б), коли лазерне випромінювання майже повністю проходить користувачу і лише частина його (з краю) вирізається краями розведеного приймача для поточного вимірювання. Для фіксації потрібного положення збірного диска 3 в корпусі 1 вимірювача при його переміщенні із зведеного положення в розведене і навпаки передбачений направляючий штифт 6, який може, наприклад, угвинчуватися в диск 3 за допомогою різьби. Переміщення із зведеного положення в розведене забезпечується за допомогою поворотного диска 7, на якому виконаний криволінійний паз 8 необхідної кривизни. Кривизна паза повинна забезпечувати до- сить легке і плавне пересування збірного диска 3 з одного його положення в інше. Для забезпечення прямолінійного руху збірного диска 3 із зведеного положення в розведене передбачений нерухомий диск 93 прямолінійним пазом 10. При цьому довжина направляючого штифта 6 має бути достатньою для проходження через паз 8 i досягнення паза 10. Рух поворотного диска 7 забезпечується за допомогою закріпленої на ньому ручки 11. При цьому поворотний диск 7 може бути встановлений у будь-якому проміжному положенні завдяки шкалі 12, нанесеній на нерухомому диску 9. Кріплення нерухомого диска 9 на корпусі 1 вимірювача може бути забезпечено, наприклад, за допомогою гвинтів 13. Аналогічно попереднім конструкціям зовнішній край виступу 2 корпусу 1 знаходиться в тепловому контакті 3 термостатом 14 з охолодженням 15, а термоелектричні батареї 16 сполучені 3 вимірювальним приладом 17 (рис. 3, в - в режимі налаштування, рис. 3, г - в режимі експлуатації). В режимі налаштування на виступі 2 корпусу 1 збірний диск 3 знаходиться в повністю зведеному положенні і суцільно перекриває лазерний пучок 5. В даному режимі приймач поглинає весь лазерний потік, і вимірювач показує абсолютне значення потужності лазерного вимірювання. Для переведення вимірювача в режим експлуатації збірний диск 3 переводиться в повністю розведене положення. Це здійснюється за рахунок криволінійного пазу 8 , 
виконаному в поворотному диску 7, при обертанні останнього за допомогою ручки 11. Глибина цього пазу (в напрямку середини диску 7) вибирається такою, щоб при повороті диска до упору краї розведеного диску 3 захоплювали апертуру вимірюваного лазерного пучка 5 , i, наприклад, до 2...5 \% потужності використовувалось для поточного та постійного вимірювання під час експлуатації. 3 іншої сторони, таке положення збірного диску 3 забезпечує проходження основної частини лазерного випромінювання для подальшого використання. При цьому кут повороту поворотного диска 7 при переході із зведеного положення в розведене вибирається таким, щоб забезпечити досить легке і плавне пересування збірного диска 3 з одного його положення в інше. Необхідно відмітити, що лазерний пучок на виході з вимірювача в режимі експлуатації має форму круглого перерізу з частково вирізаними ділянками по краях пучка (див. рис. 3, г). Проте, враховуючи, що основна потужність лазерного випромінювання зазвичай розташована в центрі пучка, а саме випромінювання в зоні обробки концентрується за рахунок фокусування, то такий недолік майже не позначається на умовах обробки таким лазерним пучком порівняно з повністю круглим пучком (без вирізаних ділянок).

Отже, пропоновані вимірювачі потужності лазерного випромінювання істотно розширюють можливості свого застосування за рахунок їх ви- користання не тільки в режимі налаштування, а й під час експлуатації лазерного обладнання.

\section{Висновки}

1. В результаті розгляду існуючих приладів для виміру енергії та потужності лазерного випромінювання запропоновані оригінальні пристрої для таких вимірів, які відрізняються простотою і надійністю та істотно розширюють можливості свого застосування

2. Запропоноване технічне рішення приймач для вимірювача енергії та потужності лазерного випромінювання, який виконаний в наборі як мінімум 3 двох приймачів: суцільного та у вигляді змінної діафрагми з центральним отвором, діаметр якого дещо менший діаметра апертури вимірюваного лазерного пучка.

3. Розроблена конструкція вимірювача потужності лазерного випромінювання, коли приймач лазерного випромінювання може бути виконаний двомісним та, окрім частини $з$ суцільним диском, містити додаткову частину у вигляді діафрагми $з$ центральним отвором, діаметр якого дещо менший діаметра апертури вимірюваного лазерного пучка.

4. Описаний розроблений варіант пристрою для вимірювання потужності лазерного пучка, де приймач випромінювання може бути збірним та знаходитися в зведеному і розведеному положенні. При цьому в зведеному положенні приймач суцільно перекриває лазерний пучок і повністю вико- 
ристовує його для виміру потужності, а в розведеному положенні - практично повністю пропускає лазерне випроміню- вання, вирізуючи для виміру його потужності по краях лазерного пучка тільки певну його частину.

1. Иващенко П. А. Измерение параметров лазеров / П. А. Иващенко, Ю. А. Калинин, Б. Н. Морозов. - М. : Издательство стандартов, 1982. 168 с. 2. Патент России № 2084843, кл. G01J5/00, 1997 г. 3. Разиньков В. В. Термоэлектрические сенсоры для измерителей мощности лазерного излучения / В. В. Разиньков, Н. Р. Бухараева, Б. М. Демчук. - М. : Термоэлектричество. - 2008. - № 4. - С. 66.

1. Ivashhenko P. A. Izmerenie parametrov lazerov / P. A. Ivashhenko, Ju. A. Kalinin, B. N. Morozov. - M. : Izdatel'stvo standartov, 1982. - $168 \mathrm{~s}$. 2. Patent Rossii № 2084843, kl. G01J5/00, 1997 g. 3. Razin'kov V. V. Termojelektricheskie sensory dlja izmeritelej moshhnosti lazernogo izluchenija / V. V. Razin'kov, N. R. Buharaeva, B. M. Demchuk. - M. : Termojelektrichestvo. -2008 . - № 4. - S. 66 .

Рецензент - В. П. Котляров, д.т.н., профессор, НТУУ «КП।» 